\title{
Author Correction: Wolbachia cifB induces cytoplasmic incompatibility in the malaria mosquito vector
}

Kelsey L. Adams, Daniel G. Abernathy, Bailey C. Willett (D), Emily K. Selland (D), Maurice A. Itoe and Flaminia Catteruccia DD Correction to: Nature Microbiology https://doi.org/10.1038/s41564-021-00998-6, published online 24 November 2021.

In the version of this article initially published, there was an error in the label of the bottom-left construct in Fig. 1a. The label has been corrected to read "vasa-cifB." The change has been made to the HTML and PDF versions of the article.
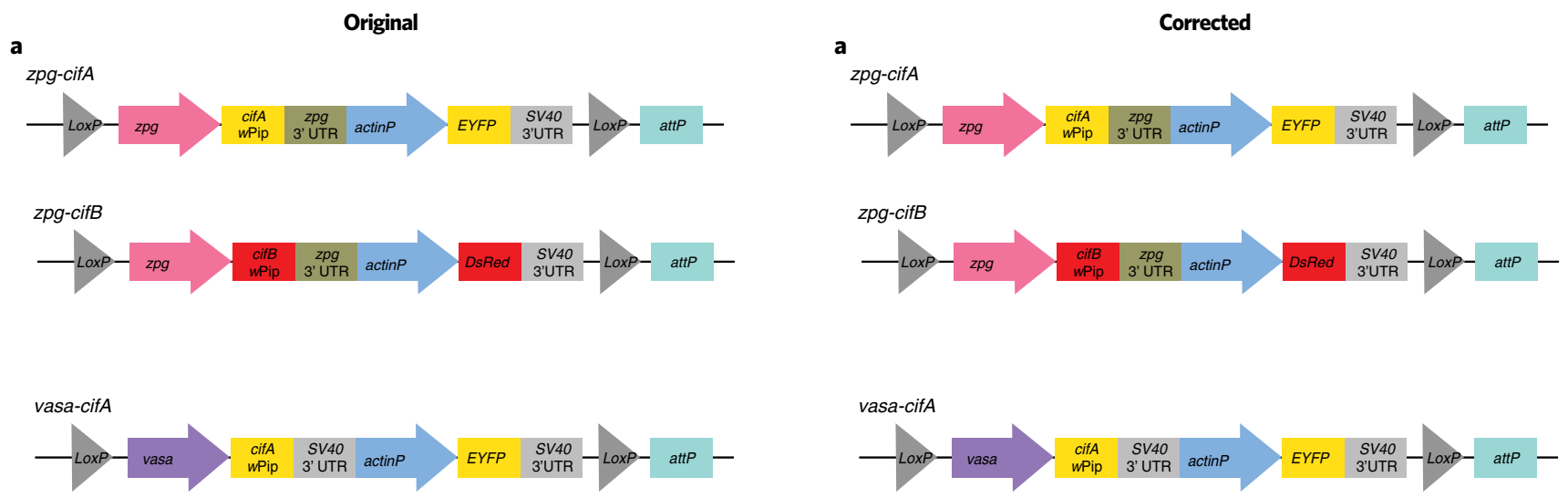

vasa-cifA
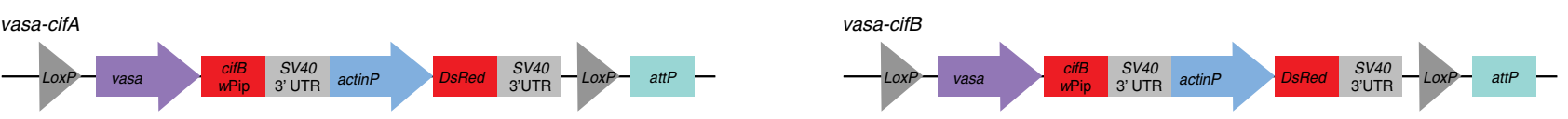

Fig. 1 | Original and Corrected.

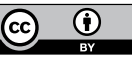

Open Access This article is licensed under a Creative Commons Attribution 4.0 International License, which permits use, sharing, adaptation, distribution and reproduction in any medium or format, as long as you give appropriate credit to the original author(s) and the source, provide a link to the Creative Commons license, and indicate if changes were made. The images or other third party material in this article are included in the article's Creative Commons license, unless indicated otherwise in a credit line to the material. If material is not included in the article's Creative Commons license and your intended use is not permitted by statutory regulation or exceeds the permitted use, you will need to obtain permission directly from the copyright holder. To view a copy of this license, visit http://creativecommons.org/licenses/ by/4.0\%.

Published online: 7 March 2022

https://doi.org/10.1038/s41564-022-01098-9

() The Author(s) 2022 